Культурно-просветительская

и благотворительная деятельность

Петра Столыпина на посту

гродненского губернатора

в 1902-1903 гг. ${ }^{1}$

\author{
Ролиан \\ Юрковский \\ доктор исторических \\ наук, профрессор, \\ Варминско- \\ Мазурский \\ университет \\ (Ольштын, Польша)
}

Петр Аркадьевич Столыпин, один из наиболее выдающихся российских политиков конца эпохи империи Романовых, после 13 лет службы в Ковенской губернии, 30 мая 1902 г. был назначен исполняющим обязанности Гродненского губернатора. Однако уже 15 февраля 1903 г. он получил должность саратовского губернатора. Таким образом, в Гродненской губернии П. А. Столыпин находился неполные девять месяцев. Однако даже за такой короткий срок столь активный общественный деятель и будущий премьер России оставил заметный след в истории Гродненской земли.

Субсидии для городского театра. В Гродно, как и ранее в Ковно, П. А. Столыпин был вынужден заниматься проблемами городского театра. Помещения театра находились в здании, соединенном с бывшим дворцом литовского подскарбия Антония Тызенгауза, где в описываемый период располагалась резиденция губернатора и некоторых губернаторских ведомств. Старшая дочь П. А. Столыпина Мария Бок так описывала городской театр в Гродно: «Трудно представить себе что-нибудь лучше этого старого замка короля польского... Под той же крышей был и городской театр, устроенный в бывшей королевской конюшне и соединенный дверью с нашим помещением. У папа́, как губернатора, была там своя ложа, и Казимир приносил нам, 
когда мы бывали в театре, чай, который мы пили в аванложе»². В осенне-зимнем сезоне 1902/03 гг. антрепренером театра в Гродно был некто Миллер, месяцами не плативший жалованья артистам и сотрудникам. Таким образом, в гродненском театре почти в точности повторилась ситуация, сложившаяся в 1899-1900 гг. в Ковно, когда П. А. Столыпину пришлось взять на себя опеку над театром, работавшим в Народном доме. 14 декабря 1902 г. на имя губернатора поступила жалоба артистов, сотрудников и билетера труппы Миллера, требующих выплаты задержанного вознаграждения. Постановлением П. А. Столыпина от 19 января 1903 г. для рассмотрения жалобы была создана специальная комиссия, в которую вошли начальник канцелярии гродненского губернатора князь Алексей Оболенский и директор театра Алексей Цветков ${ }^{3}$. Претензии работников театра были признаны справедливыми: им выплатили деньги в сумме 516 руб. из государственной субсидии, предназначенной министром внутренних дел для гродненского театра 4 . К сожалению, как и в Ковно, субсидии, направлявшиеся на «поддержку русского театра в Западном крае», вновь использовались не по назначению, а на покрытие долгов недобросовестного антрепренера.

Поддержка неофициальной части «Гродненских губернских ведомостей». По прибытии в Гродно новый губернатор не мог не обратить внимания на крайне низкий уровень материалов неофициальной части гродненского губернского органа печати. «Гродненские губернские ведомости» не шли ни в какое сравнение с аналогичной ковенской газетой, преданным читателем которой Петр Аркадьевич оставался на протяжении многих лет. Гродненской газете не хватало живости подачи информации, корреспонденций из провинции, перепечаток из газет крупных культурных центров, например из территориально близкого и богатого событиями Вильно; уровень текстов и качество редакторского материала оставляли желать много лучшего 5 . В период, когда П. А. Столыпин приступил к исполнению обязанностей губернатора, газету редактировали два сотрудника. Чиновник по фамилии Доминицкий осуществлял общее редактирование официальной части газеты, редактор В. Шенберг - ее неофициальной части. Вновь назначенный губернатор прекрасно понимал, что для повышения уровня неофициальной части «Гродненских губернских ведомостей» необходимы финансовые средства и свежие редакторские силы. Новым человеком, которому было поручено редактирование этой части губернской газеты, стал Лукьян Солоневич, отец известного белорусского общественного деятеля Яна Солоневича. С 1899 г. Солоневич-старший работал в Губернском управлении сначала в должности счетовода Губернской комиссии по делам снабжения населения ${ }^{6}$, затем, с 1902 г., в должности секретаря Статистического комитета ${ }^{7}$. Он обратил на себя внимание П. А. Столыпина своими талантливыми статьями консервативно-монархического толка, публиковавшимися в виленской прессе и «Гродненских губернских ведомостях»8. Осенью 1902 г. Л. Солоневич приступил к исполнению обязанностей редактора неофициальной части гродненской губернской газеты. Необходимые средства на развитие издания нашлись в фонде губернского Комитета попечительства о народной трезвости, который курировал губернатор. В государственном архиве Гродно хранится документ под названием «Резолюция», датированный 11 февраля 1903 г. и подписанный П. А. Столыпиным. В нем говорится о поручении, 
данном Петром Аркадьевичем Губернскому управлению - «выплатить редактору части неофициальной “Гродненских губернских ведомостей” 3000 рублей из фонда губернского Комитета попечительства о народной трезвости»9. Деньги направлялись на расширение неофициального отдела газеты в 1903 г. Губернатор точно определял размер месячной дотации: «Первые 230 рублей надлежит выплатить немедленно, а оставшиеся 210 рублей выдавать редактору каждый следующий месяц, начиная с 1 января 1903 г.»10. К «Резолюции» прилагался табель с перечислением размеров сумм выплат и целей, на которые они были предназначены. Редактор получал 50 руб. дополнительного вознаграждения (ежегодно 600 руб.), сотрудники, занимавшиеся проблемами Попечительства трезвости, и управляющие историческим отделом - по 25 руб. ежемесячно (ежегодно по 300 руб. $)^{11}$. Корреспонденты должны были получать ежемесячно 110 руб. (1320 руб. в год). Губернатор позаботился и об улучшении рабочего места редакции. Так, в смете предусматривалось 100 руб. на закупку «Энциклопедического словаря» Ф. А. Брокгауза и И. А. Ефрона, 80 руб. - на «издания, обязательно необходимые для редакции» и 300 руб. - на «непредвиденные расходы ${ }^{12}$. С результатами этого решения П. А. Столыпин уже не смог ознакомиться: перевод в Саратов отвлек его от гродненских дел. Однако произошедшие в газете перемены к лучшему были налицо. С 1903 г. неофициальная часть стала выходить всего раз в неделю, по пятницам, в ином половинном формате, нежели часть официальная. Читатели воспринимали ее как отдельное издание ${ }^{13}$. Более чем в два раза увеличился ее объем, при этом применялся удобный современный шрифт, прибавилось много новых разделов и рубрик, в частности циклы исторических статей, разнообразная корреспонденция из всех уголков губернии вместе со значительно расширившейся местной хроникой. Больше всего материалов было посвящено русским (белорусов приравнивали к русскому населению) и православию, много писали о евреях; о поляках же и католиках в газете не упоминали совсем.

Спустя годы, будучи уже председателем Совета министров Российской империи, П. А. Столыпин в одном из своих интервью подчеркнул: «Печати провинциальной и ее развитию я придаю особенное значение». Он ясно понимал, что именно провинциальная печать дает читателю богатейший срез местной жизни. Задача провинциальной печати, по мнению премьера, «верно и точно выражать настроения страны, ибо столичные газеты слишком много отдают места вопросам так называемой высокой политики и партийного политиканства» ${ }^{14}$.

Деятельность губернского Комитета попечительства о народной трезвости. Во главе губернского Комитета попечительства о народной трезвости встал губернатор. К сожалению, в материалах периодической печати пока не удалось найти конкретной информации, касающейся комитетской деятельности самого Петра Аркадьевича Столыпина. Гродненский комитет очень активно проявлял себя в деле организации народных чтений и популярных в то время передвижных выставок, где демонстрировались диапозитивы. С этой точки зрения активность Гродненского комитета значительно превосходила подобную деятельность комитетов в шести остальных губерниях Северо-Западного края. Прежде всего, в 1901 г. был создан центральный губернский склад диапозитивов и проекторов, или «волшебных фонарей», как их тогда называли. По специальным заявкам 
уездных комитетов это оборудование отправляли в города и села губернии. Согласно положению от 1 января 1902 г. склад располагал богатой коллекцией диапозитивов - всего 4234 штук. Из них 1041 касались истории России, 1065 литературы и поэзии, 724 - религиозных вопросов, 605 - географии, $614-$ других естественных наук. 185 диапозитивов рассказывали о «вреде пьянства»15. Популярность подобных выставок неуклонно росла. Так, в 1901 г. выставки посетили 34000 чел., а в 1902 г. уже 156000 чел. В отчете о деятельности Комитета за 1902 г. сообщалось, что в его мероприятиях участвовало большое количество жителей губернии: 54000 мужчин, 40000 женщин, 59000 детей и школьников ${ }^{16}$. Самой острой проблемой стала нехватка просторных помещений для выставок, особенно в небольших городках и местечках.

Развитие образования. В течение девяти месяцев работы в Гродно П. А. Столыпин много времени посвящал делам образования и учебных заведений. Он должным образом оценивал важную роль Гродно в упрочении власти и роли России в литовско-белорусских землях. В первой же докладной записке на имя министра внутренних дел В. К. Плеве П. А. Столыпин писал: «Желательно не только ассигнование на этот предмет земских сумм, но и равномерный рост расходов на них по соседним губерниям; затем самое распределение школ в разных районах губернии с различным населением имеет также первостепенное значение»17. Эта заинтересованность системой образования не являлась, однако, следствием только взглядов самого губернатора. Она имела намного более глубокие и важные причины политического свойства. Первоочередной задачей стала борьба с последствиями введенного 12 февраля 1902 г. виленским епископом Стефаном Зверовичем циркуляра № $509^{18}$. В этом документе епископ писал об отрицательном влиянии на католическое население церковно-приходских школ и так называемых школ грамоты, насаждавших, по его мнению, враждебность к католической вере и выставлявших католиков врагами государства. Циркуляр предписывал духовенству епархии строго следить за тем, чтобы дети-католики не посещали подобных учебных заведений. Именно поэтому губернатор так настойчиво защищал церковно-приходские школы в ходе заседаний губернского комитета Чрезвычайного совета.

Ко времени назначения П. А. Столыпина исполняющим обязанности гродненского губернатора центральными и губернскими властями уже были приняты решительные меры для противодействия последствиям выступления епископа С. Зверовича. То, что было начато губернатором Н. П. Урусовым, а после его отставки продолжено вице-губернатором В. Д. Лишиным, на протяжении нескольких месяцев своего управления приводил в исполнение П. А. Столыпин.

Уже в начале марта 1902 г. в Гродно стали поступать рапорты начальников уездной полиции о происшествиях, связанных с воззванием епископа ${ }^{19}$. На основе тщательного анализа этих донесений 20 марта 1902 г. канцелярия губернатора подготовила два документа: тайный циркуляр для начальников уездной полиции и полицмейстеров гродненской губернии, подписанный вице-губернатором В. Д. Лишиным ${ }^{20}$, и письмо-рапорт губернатора Н. П. Урусова, разъясняющее суть дела министру внутренних дел Д. С. Сипягину ${ }^{21}$. Вице-губернатор призывал «обратить особое внимание на деятельность католического духовенства в этом деле 
и не допускать даже малейшего проявления религиозного фанатизма и подстрекательства католиков со стороны ксендза»²2. В рапорте же губернатора министру внутренних дел содержалась следующая информация: «Результатом [воззвания епископа. - Р. Ю.] стало закрытие значительного числа церковных школ в четырех уездах гродненской губернии - Сокольском, Пружанском, Белостокском и Бельском»²3. В заключение губернатор указывал: «Пропаганда против церковно-приходских школ и их закрытие стараниями католического духовенства проистекают не только из-за религиозной ненависти, но также в силу того, что обучение в этих школах ведется не на польском языке» 24 . А 27 марта 1902 г. гродненским губернатором было издано распоряжение о начале детального расследования любых проявлений деятельности католических священников, связанной с воззванием от 12 февраля 1902 г. ${ }^{25}$ За этим последовали новые циркуляры, рапорты, доносы, жалобы ксендзов на начальников уездной полиции и т.д.

Приняв 21 июня 1902 г. управление Гродненской губернией, П. А. Столыпин сразу же столкнулся с отдельными случаями выступлений ксендзов против церковных школ. О них докладывал вновь назначенному губернатору епископ Иоахим. Такие выступления имели место в городке Одельск, селах Васильково, Порозово, Ружаны. Епископ подробно описывал их в письме П. А. Столыпину от 19 ноября 1902 г. ${ }^{26}$ Иоахим не просто перечислял фамилии священников, осуждал их «исполненную фанатизма» активность, но и настаивал на срочном вмешательстве с целью «усмирения их вредной деятельности». Губернатор никогда не пренебрегал подобными донесениями и действовал «медленно, но верно» - реагировал не спеша, зато, несомненно, продуктивно. Прежде всего, Петр Аркадьевич стремился получать информацию как минимум из двух источников. Так, 25 ноября 1902 г. по его указанию деревенскому посреднику первого округа Сокольского уезда отправили конфиденциальное письмо с поручением собрать сведения о священнике Эйлеже из городка Одельск ${ }^{27} .8$ декабря 1902 г. аналогичное распоряжение получил начальник Сокольской уездной полиции ${ }^{28}$. Ему также вменялось проверить, состоит ли население городка исключительно из католиков, или там имеются и православные прихожане. В рапорте от 17 декабря 1902 г. начальник полиции сообщал, что в Одельске «проживает 14 православных, 1313 католиков и 285 евреев, а детей в школьном возрасте: 6 православных, 125 католиков и 15 евреев» ${ }^{29}$. Подобные сведения были собраны и в других населенных пунктах, указанных в письме епископа Иоахима. Епископа очень беспокоила история «наиболее обвиняемого» ксендза Игнация Эйлежа из Одельска. 4 декабря 1902 г. ксендз Эйлеж направил губернатору жалобу на городскую полицию. Священник, в частности, писал: «Я постоянно нахожусь под надзором полиции, по причине чего пребываю в трудном и жалостном положении»30. Следствие по делу Эйлежа затянулось, что вызывало острое раздражение епископа Иохима. В официальном письме от 31 января 1903 г. он еще раз информировал П. А. Столыпина о ситуации с церковно-приходскими школами и существующем в Ружанах напряжении между католиками и православными ${ }^{31}$. Почти все эти дела, в большинстве своем незавершенные, П. А. Столыпин передал своему преемнику. Подобное положение дел отнюдь не являлось результатом медлительности действий П. А. Столыпина, 
а было лишь следствием очень краткого пребывания его в должности исполняющего обязанности гродненского губернатора.

Следует отметить нетипичное для российских чиновников того времени поведение П. А. Столыпина в деле создания новых учебных заведений, особенно в периоды обострения отношений между католиками и православными, между католическим клиром и российской административной властью. Характерен эпизод со строительством школы в деревне Пульсы, в гмине Райск Бельского уезда, известный из переписки крестьянского посредника первого округа Бельского уезда с преемником П. А. Столыпина губернатором М. М. Осоргиным. В письме от 15 июля 1903 г. новый губернатор интересовался, почему в деревне дело так и не дошло до строительства школы, хотя об этом хлопотал еще его предшественник ${ }^{32}$. М. М. Осоргин вспоминал, что крестьяне-католики деревни Пульсы обратились к П. А. Столыпину с просьбой помочь им в возведении школы. Петр Аркадьевич всецело одобрил проект, распорядившись о выделении на строительство девятисот деревянных бревен из государственного резерва Гродненской губернии. Вдобавок он «лично разговаривал с католическим ксендзом Войткунасом, приходским священником в Вышкове, чтобы тот склонил крестьян к строительству, что тот же ксендз лично обещал губернатору» ${ }^{33}$. По мнению нового губернатора, П. А. Столыпин намеренно «настаивал на участии ксендза в строительстве школы, чтобы таким образом исключить любые его шаги, направленные против задуманного строительства» ${ }^{34}$. Несмотря на все старания, дело так и не двинулось с мертвой точки. Крестьянский посредник, воодушевленный письмом П. А. Столыпина от 17 января 1903 г., в котором губернатор лично обещал ему поторопить ксендза, тщетно пытался инициировать строительство. Вскоре после этого П. А. Столыпин отправился по новому назначению в Саратов, а на деревенском сходе в апреле 1903 г. крестьяне и вовсе отказались от идеи строительства школы. По мнению крестьянского посредника, ксендз Войткунас согласился участвовать в строительном комитете, но «не проявил активности, чтобы убедить крестьян в необходимости строительства» ${ }^{35}$. Сам по себе замысел П. А. Столыпина о включении ксендза в комитет по строительству школы был не так уж плох, но лишь до момента появления циркуляра епископа С. Зверовича. После получения пасторского послания ксендз пошел на попятный, а вместе с ним от идеи строительства школы отказались и его прихожане. Они предпочли совсем не давать своим детям образование, нежели учить их под надзором православных священников. Можно предположить, что прямая заинтересованность губернатора в строительстве этой сельской школы имела под собой и политическую подоплеку. Строительство школы крестьянами-католиками для своих детей при всемерной поддержке ксендза служило бы наглядным примером того, что далеко не все католики и даже не все католическое духовенство поддерживают призывы С. Зверовича, а это было особенно важно в период обострения конфликта между государственной властью и епископом Виленским.

В местностях, где православное население составляло большинство, а строительство школ инициировали и поддерживали русские землевладельцы или чиновники, школы строили и открывали с большой торжественностью. Петр Аркадьевич лично присутствовал на открытии двух новых народных школ в Лошаньском гмине 
Гродненского уезда. Школы в деревнях Лошаны и Деречниково строили местные крестьяне под руководством Алексея Ознобишина - уездного гродненского предводителя дворянства и крестьянского посредника Михаила Пчицкого. «Гродненские губернские ведомости» поместили подробный отчет Лукьяна Солоневича о ходе этого торжества. 6 октября 1902 г. П. А. Столыпин вместе с А. А. Ознобишиным прибыли в деревню Лошаны. Вместе с жителями деревни высокие гости приняли участие в церковном богослужении. Затем с процессией они направились к новой двуклассной школе, где Петр Аркадьевич поблагодарил всех, кто способствовал возведению школы и «выразил благодарность крестьянам за мудрое стремление гарантировать образование своим детям» ${ }^{36}$. Следующей стала деревенька Ликово, где состоялось освящение уже существовавшей церковной школы. Под вечер добрались до деревни Деречниково, где губернатор, после посещения местной церкви, открыл новую школу. Там был дан обед для гостей и жителей деревни, во время которого губернатор в «своей речи, обращенной к крестьянам, напомнил слова Александра III, адресованные присутствующим на его коронации сельским старостам, и слова императора Николая II, произнесенные на маневрах в Курске - "слушайте ваших маршалков шляхты" ${ }^{37}$. Прибывших гостей, и особенно губернатора, «радостно приветствовали хлебом и солью». «Таких деревенских школ в нашей губернии еще не было», - писал Лукьян Солоневич. Сбор средств на строительство продолжался в течение пяти лет, землю под одну из школ (две десятины) даровал А. А. Ознобишин, землю (800 квадратных саженей) под другую приобрели у графини Красицкой. Бревна для строительства крестьяне получили с государственного склада, а школу возвели своими руками. Любопытной деталью этого торжественного мероприятия стала «передвижная чайная», находившаяся в ведении уездного гродненского Комитета попечительства о народной трезвости, которая «ввиду большой концентрации народа быстро распродала весь запас чая» ${ }^{38}$. На ночлег Петр Аркадьевич отправился в имение А. А. Ознобишина Новая Квасовка, находившееся неподалеку ${ }^{39}$.

Впоследствии он больше лично не посещал такого рода сельских торжеств, однако всегда высылал специальные телеграммы по случаю вновь открываемых учебных заведений. Иное дело - губернский город, где на подобных мероприятиях губернатор просто не мог не присутствовать. 1 октября 1902 г. в Гродно состоялось открытие новой двухгодичной женской школы с классом профессионального обучения портновскому ремеслу, подведомственной Министерству просвещения. В здании новой школы на улице Муравьевской когда-то располагалась фабрика по производству бондарных изделий, главный цех которой теперь был «разделен стенами и было образовано 3 классных помещения, учительская комната, раздевалка для девочек и квартиры для учителей, состоящие из двух комнат и кухни» ${ }^{40}$. По мнению репортера местной газеты, «помещения были светлые, просторные, производившие исключительно приятное впечатление». Вместе с несколькими губернскими сановниками (епископ Иоахим, губернский инспектор народных школ, инспектор мужских гимназий, губернский предводитель дворянства, чиновник специальных поручений Александр фон Петерсон) на открытие школы прибыл и П. А. Столыпин. С пространной речью перед собравшимися выступил инспектор народных школ Неофит Богородский, подчеркнув заслуги бывшего губернатора 
князя Н. П. Урусова в деле создания и организации школы ${ }^{41}$. Это была первая подобного рода женская школа в Гродненской губернии - уже в день ее открытия в нее записались 49 учениц.

Через месяц с небольшим в Гродно открылось еще одно, единственное в своем роде, учебное заведение - двуклассная еврейская мужская школа с женской сменой. За три года обучения здесь получали знания по русскому языку, арифметике, истории, географии, каллиграфии и естествознанию42. А 10 ноября 1902 г. П. А. Столыпин принимал участие в юбилейных торжествах по случаю 10-летия существования женской воскресной школы при Гродненском православном братстве св. Софьи ${ }^{43}$. Как и в воскресной школе, празднование проходило с большим размахом. Среди приглашенных и присутствовавших гостей рядом с губернатором и епископом Иоахимом находились: губернский предводитель дворянства Петр Веревкин, инспектор народных школ Алексей Вышеславцев, генерал Евстахий Скупио ${ }^{44}$. Епископ и инспектор народных школ выступили с речами. Все ученицы школы получили «крестик или иконки от епископа, пакетики со сладостями от Петра Столыпина, а от председателя совета Братства - брошюрку о десятилетней истории школы» 45 .

Достаточно красноречивым было присутствие губернатора на торжествах по случаю 10-летия воскресной школы православного братства и отсутствие его на открытии начальной школы, имеющей большее значение для еврейского населения Гродно ${ }^{46}$. Последней школой, которую открыл в Гродно губернатор П. А. Столыпин, стала двуклассная мужская приходская школа, подведомственная Министерству просвещения. Выступая с речью 6 декабря 1902 г. на торжественном освящении помещений этого учебного заведения, он выразил желание, чтобы «город Гродно дошел до всеобщего обучения» ${ }^{47}$. Хотя эти слова остались лишь добрым пожеланием, процент новых школ, открытых в Гродненской губернии в 1902 г., был достаточно высок. Как следует из отчета дирекции народных школ за 1902 г., опубликованного в «Гродненских губернских ведомостях», только в том году состоялось открытие 47 новых школ, преобразовано еще 8 школ. Среди них 9 приходских школ, 29 народных начальных школ, 3 подконтрольные Министерству просвещения еврейские школы, 4 частных школы, 2 школы, перешедшие на новый, более высокий уровень обучения ${ }^{48}$.

Благотворительная деятельность Ольги и Петра Столыпиных. В самом Гродно и в Гродненской губернии с 20 апреля 1902 г. и до 1 октября 1902 г. существовали, согласно спискам, представленным уездной администрацией, 43 благотворительных общества ${ }^{49}$. В перечне приведены восемь таких обществ в Гродно и четыре - в Гродненском уезде. Больше всего благотворительных обществ (16) действовало в Белостоке - самом крупном городе губернии. В уездах, Сокольском и Кобринском, такого типа обществ вообще не отмечено ${ }^{50}$. Наиболее активным в столице губернии было Гродненское благотворительное общество. Согласно традиции, существовавшей в западных губерниях, руководили подобными обществами жены губернаторов. Так было в Ковно, такая практика существовала и в Гродно, когда 12 сентября 1902 г. общее собрание членов Гродненского благотворительного общества, заседавшее под председательством жены вице-губернатора Ольги Лишиной, единогласно выбрало Ольгу Столыпину своим председателем. 
Директором Общества стал губернский предводитель дворянства П. Веревкин ${ }^{51}$. Деятельность нового председателя не отличалась от работы ее предшественниц. Устраивались благотворительные концерты, моментальные лотереи, собирались средства на празднование Рождества и Пасхи.

Судя по объему информации, попадавшей в местные газеты, количество благотворительных мероприятий, проводившихся в Ковно, намного превышало их число в Гродно. Главной тому причиной являлась, конечно, намного более насыщенная событиями общественная жизнь Ковно. На объем подобной информации оказывал влияние и низкий уровень неофициальной части главной газеты города - «Гродненских губернских ведомостей». Благодаря дотациям П. А. Столыпина, как уже отмечалось выше, перемены к лучшему стали очевидны к началу 1903 г., однако для историка, изучающего общественную деятельность супружеской четы Столыпиных в гродненский период, это слабое утешение, поскольку 15 февраля 1903 г. Петр Аркадьевич покидает город и становится саратовским губернатором.

Тем не менее в период пребывания четы Столыпиных в Гродно здесь состоялась грандиозная «моментальная лотерея», организованная Гродненским благотворительным обществом 24 ноября 1902 г. Лотерея принесла 2270 руб. дохода, что было самой крупной суммой с 1899 г.52 Число разного рода благотворительных акций возрастало в период религиозных праздников. А в декабре 1902 г. - январе 1903 г. прошел сбор средств для малообеспеченных учеников гродненской мужской гимназии. К концу декабря размер пожертвований составил 180 руб., из них 15 руб. внес Петр Аркадьевич Столыпин ${ }^{53} .12$ января 1903 г. Столыпины приняли участие в музыкально-литературном вечере в пользу бедных учеников, завершившемся балом для приглашенных гостей. По сообщению газеты «Гродненские губернские ведомости», «в первой паре полонеза танцевала Ольга Столыпина с главным распорядителем бала студентом Буткевичем, в другой паре сам губернатор - с организатором бала А. Будиловой» ${ }^{4}$. Во время вечера продавали шампанское, мороженое, цветы, игрушки. Всего было собрано 945 руб.

Столыпины провели в Гродно только одно Рождество. Для обоих супругов это был очень насыщенный делами период. 27 декабря 1902 г., «благодаря заботе и стараниям возглавлявшей городское благотворительное общество - Ольги Столыпиной, в местной тюрьме была организована елка для 23 детей заключенных вместе с их родителями „55. В елке участвовала вся семья губернатора вместе с детьми. Из газетной хроники: «Глава губернии поздоровался с арестантами, среди которых были осужденные на каторгу, которые завтра под конвоем покидали тюрьму. Супруга главы губернии, сердечно обнимая детей, раздавала им праздничные подарки ${ }^{56}$. Это беспрецедентное событие в гродненской тюрьме «произвело на всех сильное впечатление» 57 . Уже на следующий день, 28 декабря 1902 г., в Дворянском собрании, также по инициативе жены губернатора, была организована елка и моментальная лотерея в пользу Гродненского благотворительного общества. «Играл военный оркестр, лакеи разносили напитки, разыгрывались игрушки... Доход составил 171 рубль», - писала местная пресса ${ }^{58} .26$ января 1903 г. состоялся спектакль в пользу сиротского приюта при Благотворительном обществе, который принес 222 руб. дохода. В печати сообщалось, что губернатор пожертвовал 15 рублей, вице-губернатор - 2 руб. ${ }^{59}$ Для сбора денег в пользу 
бедных воспользовались присутствием в Гродно генерал-губернатора князя П. Д. Святополк-Мирского. На любительском театральном спектакле, состоявшемся 7 февраля 1903 г., самым большим жертвователем стал генерал-губернатор 100 руб. ${ }^{60}$ Собирали средства и для нужд Гродненского отделения Общества сестер милосердия и отдела Красного Креста. С этой целью 22 декабря 1902 г. был дан любительский спектакль, собравший 227 руб., из которых 15 руб., поступивших от губернатора, оказались самой большой суммойб1.

Другой хорошей традицией, введенной в Гродно П. А. Столыпиным, стали пожертвования в пользу Гродненского благотворительного общества вместо обычных праздничных визитов и почтовых поздравительных открыток. Пожертвования вносились после речей и тостов на праздничных обедах с шампанским, чаем и пирожными. Об этом сообщала гродненская пресса в первые дни нового 1903 г.: «По инициативе его превосходительства главы губернии, новогодние визиты и отправление открыток с пожеланиями заменяются на взаимные пожелания в доме гражданских собраний, в пользу местного благотворительного общества. Эти пожелания друг другу приносят 1 января после богослужения в соборе»62. На подобных встречах в январе 1903 г. было собрано 625 руб. Средства таким способом собирали и исправники в уездах. Такие формы пополнения средств Гродненского благотворительного общества сохранились и после того, как Столыпины покинули Гродно. На Пасху 1903 г. число лиц, вносивших пожертвования, увеличилось в десятки раз ${ }^{63}$.

Вскоре после приезда в Гродно Ольга Столыпина стала почетным членом женского кружка при православном Братстве Святой Софии, который возглавляла Ольга Лишина, супруга вице-губернатора. Это общество занималось организацией помощи нищим приверженцам православия - хлопотало об обеспечении бездомных жильем, помогало им пропитанием и одеждой. Ольга Столыпина постоянно вносила пожертвования в кассу подопечного кружка. Так, 24 февраля 1903 г. после любительского спектакля, организованного участницами кружка, самым крупным взносом (15 руб.) стало пожертвование Ольги Столыпиной. Всего же во время спектакля на благотворительные нужды удалось собрать 323 руб. 64

Даже в краткий 9-месячный период работы в Гродно П. А. Столыпин проявил свои замечательные организаторские способности, энергию и общественную активность. Целью Петра Аркадьевича Столыпина была идея служения России и династии Романовых. Лишь нехватка времени не позволила П. А. Столыпину развернуть более широкую общественно-культурную деятельность, которой до этого он отдавался с такой самоотверженностью на месте губернского предводителя дворянства Ковенской губернии. Опыт руководства П. А. Столыпина Гродненской губернией, населенной белорусами, литовцами, поляками, евреями, русскими, несомненно, повлиял на его отношение к национальным проблемам Российской империи. Ковенские и гродненские годы стали самыми счастливыми для его семьи. Это были последние спокойные годы и для всей России. Уже в 1903 г. в саратовской губернии П. А. Столыпин столкнется с таким накалом политических страстей, которого в спокойном Гродно он даже и не мог себе представить. Гродненский период 


\section{деятельности П. А. Столыпина стал своеобразной прелюдией к его губернаторству в Саратове во время бурного начала первой российской революции 1905-1907 гг.}

1 Перевод с польского д-ра ист. наук Л. М.Аржаковой.

2 Бок М. П. Воспоминания о моем отце П. А. Столыпине // Российские судьбы. Жизнеописания, факты и гипотезы, портреты и документы в 30 книгах. Москва, 1998. С. 64. - Мария Бок путает дворец короля Станислава Августа Понятовского с дворцом Антония Тызенгауза. Театр в Городнице, учрежденный в 1784 г. в королевском манеже, затем был соединен с дворцовым флигелем, или - в будущем - с домом губернатора. Подробную информацию о судьбе этого театра см.: Ендрыховский 3. Гродненские театры 1784-1864. Варшава, 2012. - Там же помещены фотография дома губернатора (С. 19) и фрагмент плана Городницы (С. 100).

3 О выдаче гродненскому театру правительственной субсидии в размере 1000 рублей // Национальный исторический архив Беларуси в городе Гродно (далее - НИАБ-Гродно). Ф.1. Оп. 25. Д. 591. Л. 14.

4 Там же. - В этом же архивном деле имеется копия письма губернатора Н. П. Урусова от 10 января 1902 г., адресованного в Департамент общих дел Министерства внутренних дел по вопросу признания субсидий для Гродненского театра в размере 1000 рублей (Л. 2).

5 Экземпляры газет второй половины 1902 г., доступные в виде микрофильма в Российской национальной библиотеке Санкт-Петербурга, практически не читаются, однако не из-за качества микрофильма, а по причине крайне низкого качества печати самой газеты.

6 Ціхаміраў А. Саланевічвы і Гродна // Arche. 2010. № 1-2. С. 187.

7 Используя статистические данные, в августе и сентябре 1902 г. он опубликовал за подписью «Солон-ъ» объемную, состоящую из трех частей статью исторического содержания с примечаниями: Солон-ъ. Частновладельческое хозяйство в Гродненской губернии в прошлом и настоящем // Гродненские губернские ведомости. Отдел неофициальный (далее - ГГВ-О/н). 1902. № 66. 20 авг. Ч. I; № 68. 27 авг. Ч. II; № 70. 3 сент. Ч.ІІІІ.

8 Подробнее об этом см.: Никандров Н. Иван Солоневич. Народный монархист. М., 2007. С. 20; Черепица В. Н. П.А. Столыпин (1862-1911) - гродненский губернатор и великий реформатор России // История Гродненщины XIX столетия в событиях и лицах (исследования, документы, комментарии). Гродно, 2003. С. 22.

9 О расходовании денег, отпускаемых Комитетом попечительства о народной трезвости на расширение неофициальной части «Гродненских губернских ведомостей» // НИАБ-Гродно. Ф.2. Оп. 19. Д. 2822. Л. 1.

10 Там же.

11 Ежегодная выплата 300 руб. в виде вознаграждения для редактора отдела, который освещал деятельность Комитета попечительства о народной трезвости, должна была стать обоснованием предоставляемой из фондов губернского Комитета дотации.

12 Там же. Л. 2.

13 Хроника // ГГВ-О/н. 1902. № 104. 31 дек.

14 Беседа с редактором газеты «Волга» // Голос Москвы. 1909. № 345. 4 окт.

15 Отчет гродненского губернского комитета Попечительства о народной трезвости за 1902 год // Памятная книжка Гродненской губернии на 1903 год. Гродно, 1903. С. 106.

16 Отсутствуют данные о 2000 лицах (Там же. С. 104-105).

17 Стольюпин П.А. Грани таланта политика. М., 2006. С. 44.

18 Пасторское письмо сопровождалось циркуляром, в котором под угрозой «неотпущения грехов во время причастия детям, их родителям и опекунам» всем католикам запрещалось посылать детей в церковно-приходские школы и так называемые школы грамоты, находившиеся в ведении православного духовенства. Подробнее см.: Merkys V. Tautiniai santykiai. Vilniaus vyskupijoje 1798-1918. Vilnius, 2006.

19 Переписка с уездными исправниками и виленской католической епархией о вмешательстве католического духовенства в дела церковно-приходских училищ. 20 марта 1902 г. 2 октября 1902 г. // НИАБ-Гродно. Ф. 1. Оп. 18. Д. 853. Л. 2-9. 
20 Там же. Л. 14.

21 О постройке церковно-приходских школ в Гродненской губернии и о вредной деятельности ксендзов против этой постройки. 25 ноября 1902 г. - 16 ноября 1903 г. // НИАБ-Гродно. Ф. 1. Оп. 18. Д. 849. Л. 6.

22 Переписка с уездными исправниками и виленской католической епархией о вмешательстве католического духовенства в дела церковно-приходских училищ. 20 марта 1902 г. 2 октября 1902 г. // НИАБ-Гродно. Ф.1. Оп. 18. Д. 853. Л. 14.

23 О постройке церковно-приходских школ в Гродненской губернии и о вредной деятельности ксендзов против этой постройки. 25 ноября 1902 г. - 16 ноября 1903 г. // НИАБ-Гродно. Ф.1. Оп. 18. Д. 849. Л. 7.

24 Там же.

25 Переписка с уездными исправниками и виленской католической епархией о вмешательстве католического духовенства в дела церковно-приходских училищ. 20 марта 1902 г. 2 октября 1902 г. // НИАБ-Гродно. Ф. 1. Оп. 18. Д. 853. Л. 15-16.

26 О постройке церковно-приходских школ в Гродненской губернии и о вредной деятельности ксендзов против этой постройки. 25 ноября 1902 г. - 16 ноября 1903 г. // НИАБ-Гродно. Ф. 1. Оп. 18. Д. 849. Л. 12-13.

27 Там же. Л. 24.

28 Там же. Л. 14.

29 Там же. Л. 15.

30 Там же. Л. 21.

31 Переписка с уездными исправниками и виленской католической епархией о вмешательстве католического духовенства в дела церковно-приходских училищ. 20 марта 1902 г. 2 октября 1902 г. // НИАБ-Гродно. Ф. 1. Оп. 18. Д. 853. Л. 10-11.

32 О постройке церковно-приходских школ в Гродненской губернии и о вредной деятельности ксендзов против этой постройки. 25 ноября 1902 г. - 16 ноября 1903 г. // НИАБ-Гродно. Ф.1. Оп. 18. Д. 849. Л. 58.

зз Там же.

34 Там же.

35 Там же. Л. 59.

36 Хроника // ГГВ-О/н. 1902. № 81. 11 окт.

37 Там же.

38 Там же. - Сама идея организовать передвижные чайные появилась в уездном Гродненском комитете, возглавляемом Алексеем Ознобишиным, о чем сообщается в отчете о деятельности комитета в 1902 г.: «Поистине, это благая мысль. Хотя народ наш к чаю еще не привык и потребление его в деревне очень слабо, но в праздничные дни в деревне найдется и немало желающих “покушать чайку”. Комитет решил открыть передвижные чайные» (Отчет о деятельности уездного Гродненского комитета за 1902 г. // ГГВ-О/н. 1902. № 76.24 нояб.).

39 В своих воспоминаниях Алексей Ознобишин пишет только: «Столыпин посещал меня в моем имении Новая Квасовка, и вообще я с ним был в самых дружеских отношениях» (Ознобишин A. А. Воспоминания члена IV Государственной Думы. Париж, 1927. С. 178).

40 Хроника // ГГВ-О/н. 1902. № 78. 1 окт.

41 Хроника // ГГВ-О/н. 1902. № 80. 8 окт.

42 Хроника // ГГВ-О/н. 1902. № 89. 8 нояб.

43 Хроника // ГГВ-О/н. 1902. № 90. 12 нояб.

44 Хроника // Гродненские епархиальные ведомости. 1902. № 47. 24 нояб.

45 Там же. - Брошюра называлась «К десятилетию Гродненской Братской школы. За 10 лет ея существования». Ее автором был А.А. Вышеславцев - бывший директор школы и по совместительству издатель газеты «Гродненские епархиальные ведомости».

46 Согласно переписи еврейского населения, в Гродно на 1 января 1902 г. было около 1500 еврейских мальчиков и 1800 девочек школьного возраста. Из этого числа 2/3 мальчиков и 3/4 девочек не посещали ни одну школу (Школьное образование в Гродно // ГГВ-О/н. 1902. № 89.8 нояб.).

47 Хроника // ГГВ-О/н. 1902. № 101. 20 дек. 
48 Хроника // ГГВ-О/н. 1903. № 3. 17 янв.

49 Списки благотворительных обществ в губернии // НИАБ-Гродно. Ф.1. Оп. 18. Д. 839. Л.1-24. - Для сравнения: в 1898 г. в Ковно действовали 11 благотворительных обществ, не считая еврейских (Памятная книжка Ковенской губернии на 1898 год. Ковно, 1897. С. 241-243).

50 Списки благотворительных обществ в губернии // НИАБ-Гродно. Ф.1. Оп. 18. Д. 839. Л. $4,16$.

${ }^{51}$ Хроника // ГГВ-О/н. 1902. № 74.17 сент.

52 Там же. № 94.26 нояб. — В 1899 г. собрано — 2305 руб., в 1897 г. — 1911 руб., в 1898 г. — 1800 руб., в 1900 г. - 2190 руб., в 1901 г. — 2071 руб.

53 Там же. № 101. 20 дек.

54 Там же. 1903. № 3. 17 янв.

55 Там же. № 1.3 янв.

56 Там же.

57 В Ковно П.А. Столыпин стал одним из основателей и попечителей Ковенского приюта для арестантских детей (устав утвержден 16 мая 1898 г.).
58 Там же
59 Там же. № 8.21 февр.
60 Там же.
61 Там же. № 4. 24 янв.
62 Там же. № 2. 10 янв.
63 Там же. № 15. 18 апр.
${ }_{64}$ Там же.

\section{ДЛЯ ЦИТИРОВАНИЯ}

Юрковский Р. Культурно-просветительская и благотворительная деятельность Петра Столыпина на посту гродненского губернатора в 1902-1903 гг. // Новейшая история России. 2017. № 3 (20). С. 49-62. УДК 94(47).083

Аннотация: Личности Петра Аркадьевича Столыпина посвящено огромное количество книг, научных статей, воспоминаний, изданных как в России, так и за рубежом. Однако среди научных публикаций, посвященных этому выдающемуся государственному деятелю, практически нет работ, освещающих его деятельность в Гродненской губернии, которой П. А. Столыпин руководил некоторое время как исполняющий обязанности губернатора. В данной статье предпринята одна из первых попыток восполнить этот пробел. Гродненский период деятельности П. А. Столыпина стал своеобразной прелюдией к его губернаторству в Саратове во время бурного начала первой российской революции 1905-1907 гг. Опыт руководства П. А. Столыпина Гродненской губернией, населенной белорусами, литовцами, поляками, евреями, русскими, несомненно, повлиял на его отношение к национальным проблемам Российской империи. Статья показывает П. А. Столыпина как русского чиновника в окраинном регионе Российской империи. Он занимался открытием церковно-приходских школ и школ грамоты при православных храмах, работой русского театра в Гродно, развитием русской периодической печати, попечительством о народной трезвости, поддержкой православных благотворительных обществ, и в целом был выдающимся деятелем губернской администрации. Его проекты и инициативы значительно превосходили формальные чиновничьи обязанности. Статья написана на основе периодической печати того времени, воспоминаний современников П. А. Столыпина, а также архивных документов Национального исторического архива Беларуси в городе Гродно, часть из которых впервые вводится в научный оборот.

Ключевые слова: П.А.Столыпин, Гродненская губерния, окраина, Российская империя, культурно-просветительская деятельность, благотворительная деятельность, Русская православная церковь, начало XX В. 
Сведения об авторе: Юрковский Р. - доктор исторических наук, профессор, Варминско-Мазурский университет (Ольштын, Польша); roman.jurkowski@uwm.edu.pl

\title{
FOR CITATION
}

Jurkowski R. Cultural, Educational and Charitable Activities of Pyotr Stolypin as Governor of Grodno in 1902-1903, Modern History of Russia, no. 3, 2017, pp. 49-62.

\begin{abstract}
Absrtact: Personality of Peter Stolypin is devoted to a huge number of books, scientific articles and memoirs, published in Russia and abroad. However, among the scientific publications dedicated to this outstanding statesman, almost no work, covering his work in Grodno province, where P. A. Stolypin oversaw some time as acting Governor. The article describes one of the first attempts to fill this gap. The Grodno period of Stolypin's activity was a prelude to his governorship in Saratov during the turbulent outbreak of the first Russian revolution of 1905-1907. Leadership experience of P. A. Stolypin Grodno province, inhabited by Belarusians, Lithuanians, Poles, Jews, Russians, doubtless, influenced his attitude towards the national problems of the Russian Empire. The article shows P. A. Stolypin as a Russian officer in the outlying region of the Russian Empire (opening of parish schools and the "schools of letters" with the Orthodox churches, the work of the Russian theatre in Grodno, the development of Russian periodicals, the guardianship of people's sobriety, support of charity societies) and, in general, as the outstanding figure of the provincial administration. His projects and initiatives were significantly beyond the formal bureaucratic duties. The article is based on the periodicals of that time, memoirs of contemporaries of P. A. Stolypin, as well as of archival documents of the National historical archives of Belarus in Grodno, part of which was first introduced in the scientific circulation.
\end{abstract}

Keywords: P.A. Stolypin, Grodno Province, Remote Area, Russian Empire, Cultural Activity, Charity, Russian Orthodox Church, Early Twentieth Century.

Author: Jurkowski R. - Doctor of History, Professor, University of Warmia and Mazury (Olsztyn, Poland); roman. jurkowski@uwm.edu.pl

\section{References:}

Bok M. P. 'Vospominaniya o moem ottse P. A. Stolyipine', Rossiyskie sudby. Zhizneopisaniya, fakty i gipotezy, portrety i dokumenty, v 30 knigakh (Moscow, 1998).

Cherepitsa V.N. 'P. A. Stolyipin (1862-1911) — grodnenskiy gubernator i velikiy reformator Rossii', Istoriya Grodnenschinyi XIX stoletiya v sobytiyakh i litsakh (issledovaniya, dokumenty, kommentarii) (Grodno, 2003).

Endrykhovskiy Z. Grodnenskie teatryi 1784-1864 (Warsaw, 2012).

Merkys V. Tautiniai santykiai. Vilniaus vyskupijoje 1798-1918 (Vilnius, 2006).

Nikandrov N. Ivan Solonevich. Narodnyi monarkhist (Moscow, 2007).

Oznobishin A. A. Vospominaniya chlena IV Gosudarstvennoy Dumy (Paris, 1927).

Stolyipin P. A. Grani talanta politika (Moscow, 2006).

Tsikhamirav A. 'Salanevichvy i Grodna', Arche, no. 1-2, 2010. 